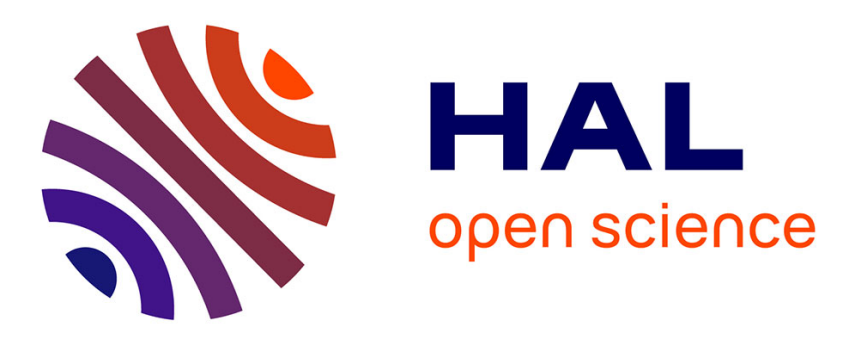

\title{
Effect of surface waxes on the persistence of chlorpyrifos-methyl in apples, strawberries, and grapefruits
}

Rossella Riccio, Marco Trevisan, Ettore Capri

\section{- To cite this version:}

Rossella Riccio, Marco Trevisan, Ettore Capri. Effect of surface waxes on the persistence of chlorpyrifos-methyl in apples, strawberries, and grapefruits. Food Additives and Contaminants, 2006, 23 (07), pp.683-692. 10.1080/02652030600627248 . hal-00577591

\section{HAL Id: hal-00577591 \\ https://hal.science/hal-00577591}

Submitted on 17 Mar 2011

HAL is a multi-disciplinary open access archive for the deposit and dissemination of scientific research documents, whether they are published or not. The documents may come from teaching and research institutions in France or abroad, or from public or private research centers.
L'archive ouverte pluridisciplinaire HAL, est destinée au dépôt et à la diffusion de documents scientifiques de niveau recherche, publiés ou non, émanant des établissements d'enseignement et de recherche français ou étrangers, des laboratoires publics ou privés. 


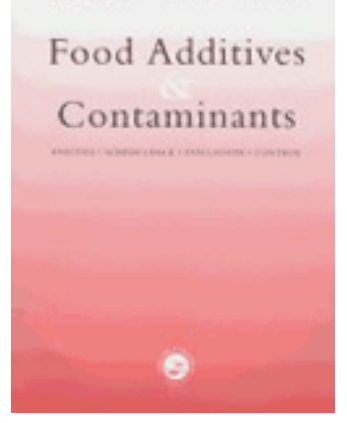

\section{Effect of surface waxes on the persistence of chlorpyrifos- methyl in apples, strawberries, and grapefruits}

\begin{tabular}{|r|l|}
\hline Journal: & Food Additives and Contaminants \\
\hline Manuscript ID: & TFAC-2005-397.R1 \\
\hline Manuscript Type: & Original Research Paper \\
\hline Author: & 05-Feb-2006 \\
\hline Complete List of Authors: & $\begin{array}{l}\text { Riccio, Rossella; Università Cattolica del Sacro Cuore, Istituto di } \\
\text { Chimica Agraria ed Ambientale sez Chimica Vegetale } \\
\text { Trevisan, Marco; Università Cattolica del Sacro Cuore, Istituto di } \\
\text { Chimica Agraria ed Ambientale sez Chimica Vegetale } \\
\text { Capri, Ettore; Università Cattolica del Sacr Cuore, Istituto di } \\
\text { Chimica Agraria ed Ambientale sez Chimica Vegetale }\end{array}$ \\
\hline Methods/Techniques: & Chromatography - GC/MS \\
\hline Additives/Contaminants: & Pesticide residues, chlorpyrifos-methyl \\
\hline Food Types: & Fruit \\
\hline & \\
\hline
\end{tabular}

\section{SCHOLARONE Manuscripts}




\begin{tabular}{ll}
\hline FRUIT & WAX $\left(\mu \mathrm{g} / \mathrm{cm}^{2}\right)$ \\
\hline Strawberry & 22 \\
Grapefruit & 130 \\
Apple & 516 \\
Control & 0 \\
\hline
\end{tabular}

| Table1. Waxes extracted from fruits. 
I

$$
\text { grapefruit }
$$

fraction 4

Table 2. Chlorpyrifos-methyl residues on grapefruits with and without wax $\left(\mu \mathrm{g} \mathrm{g}^{-1}\right)$. P.t.:pesticide treatment.
Deleted: Table 2. Recoveries of diatomaceous earth extraction procedure applied to apple samples fortified with chlorpyrifos-methyl. a Average and relative standard deviation, $n=3$. II II

\begin{tabular}{clc} 
yl residue $\left(\mu \mathrm{g} \mathrm{g}^{-1}\right)$ & Chlorpyrifos-methyl residue $\left(\mu \mathrm{g} \mathrm{g}^{-1}\right)$ \\
\hline $0.012 \pm 0.001$ & $<\mathrm{LOQ}$ & $0.014 \pm 0.001$ \\
$0.012 \pm 0.001$ & $<\mathrm{LOQ}$ & $0.013 \pm 0.001$ \\
$0.008 \pm 0.001$ & $<\mathrm{LOQ}$ & $0.009 \pm 0.001$ \\
$0.013 \pm 0.001$ & $<\mathrm{LOQ}$ & $0.047 \pm 0.004$ \\
$<$ LOQ & $<\mathrm{LOQ}$ & $<\mathrm{LOQ}$ \\
$<$ LOQ & $<\mathrm{LOQ}$ & $<\mathrm{LOQ}$ \\
\hline \multicolumn{3}{l}{}
\end{tabular}




\begin{tabular}{|c|c|c|c|c|}
\hline \multirow[t]{3}{*}{ apple } & \multicolumn{2}{|c|}{ Wax intact } & \multicolumn{2}{|c|}{ Wax removed } \\
\hline & untreate & fortified & untreated & fortified \\
\hline & \multicolumn{2}{|c|}{ Chlorpyrifos-methyl residue $\left(\mu \mathrm{g} \mathrm{g}^{-1}\right)$} & \multicolumn{2}{|c|}{ Chlorpyrifos-methyl residue $\left(\mu \mathrm{g} \mathrm{g}^{-1}\right)$} \\
\hline whole $1 \mathrm{~h}$ after $\mathrm{p} \mathrm{t}$ & $<\mathrm{LOQ}$ & $0.020 \pm 0.002$ & $<\mathrm{LOQ}$ & $0.025 \pm 0.003$ \\
\hline whole $24 \mathrm{~h}$ after $\mathrm{pt}$ & $<\mathrm{LOQ}$ & $0.021 \pm 0.003$ & $<\mathrm{LOQ}$ & $0.024 \pm 0.003$ \\
\hline fraction 1 & $<\mathrm{LOQ}$ & $0.010 \pm 0.001$ & $<$ LOQ & $0.014 \pm 0.002$ \\
\hline fraction 2 & $<\mathrm{LOQ}$ & $0.095 \pm 0.006$ & $<\mathrm{LOQ}$ & $0.129 \pm 0.007$ \\
\hline fraction 3 & $<\mathrm{LOQ}$ & $0.002 \pm 0.001$ & $<$ LOQ & $0.002 \pm 0.001$ \\
\hline fraction 4 & $<$ LOQ & $<\mathrm{LOQ}$ & $<\mathrm{LOQ}$ & $<$ LOQ \\
\hline
\end{tabular}

Table 3. Chlorpyrifos-methyl residues on apples, with and without wax $\left(\mu \mathrm{g} \mathrm{g}^{-1}\right)$. P.t.: pesticide treatment. 


\begin{tabular}{|c|c|c|c|c|c|}
\hline \multirow[t]{3}{*}{ strawberry } & \multicolumn{2}{|c|}{ Wax intact } & \multicolumn{2}{|c|}{ Wax removed } & \\
\hline & untreate & fortified & untreated & fortified & \\
\hline & \multicolumn{2}{|c|}{ Chlorpyrifos-methyl residue $\left(\mu \mathrm{g} \mathrm{g}^{-1}\right)$} & \multicolumn{2}{|c|}{ Chlorpyrifos-methyl residue $\left(\mu \mathrm{g} \mathrm{g}^{-1}\right)$} & \\
\hline whole $24 \mathrm{~h}$ after $\mathrm{pt}$ & $<$ LOQ & $0.022 \pm 0.003$ & $<\mathrm{LOQ}$ & $0.028 \pm 0.003$ & \\
\hline fraction 1 & $<$ LOQ & $0.008 \pm 0.001$ & $<\mathrm{LOQ}$ & $0.013 \pm 0.002$ & \\
\hline fraction 2 & $<\mathrm{LOQ}$ & $0.015 \pm 0.003$ & $<\mathrm{LOQ}$ & $0.015 \pm 0.003$ & \\
\hline
\end{tabular}
treatment. 


\begin{tabular}{lllll}
\hline FRUIT & \multicolumn{3}{c}{ Chlorpyrifos-methyl } & $\mathrm{TCP}$ \\
\cline { 2 - 5 } & $\mathrm{T}_{1 / 2}(\mathrm{~min})$ & $\mathrm{R}$ & $\mathrm{T}_{1 / 2}(\min )$ & $\mathrm{R}$ \\
\hline Strawberry & 26 & -0.96 & 14 & -0.95 \\
Grapefruit & 34 & -0.97 & 29 & -0.97 \\
Apple & 83 & -0.99 & 80 & -0.98 \\
Control & 9.6 & -0.99 & n. d. & n.d. \\
\hline
\end{tabular}

| Table 5. Half life $\left(\mathrm{t}_{1 / 2}\right)$ and correlation coefficient $(\mathrm{r})$ of chlorpyrifos-methyl and TCP in fruit wax extracts after exposure to irradiation. N.d.: not determinated. 
<smiles>COP(=S)(OC)Oc1nc(Cl)c(Cl)cc1Cl</smiles>

A

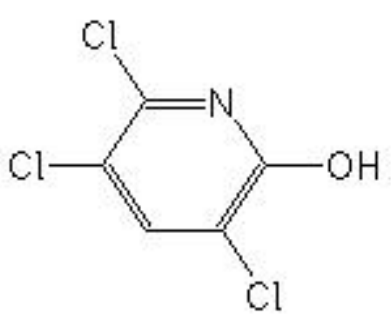

B

Figure 1. A: chlorpyrifos-methyl, B: 3,4,5-trichloro 2-pyridinol (TCP). 


\section{FRUIT SAMPLES}

(with and without wax) immersed for 15 seconds in aqueous suspension of pesticide $1 \mathrm{~mL} \mathrm{~L}^{-1}$



total amount of pesticide

Fraction 1

Rinsed fruit



diatomaceous earth extraction

GC-MS analysis

Peeled Fruit

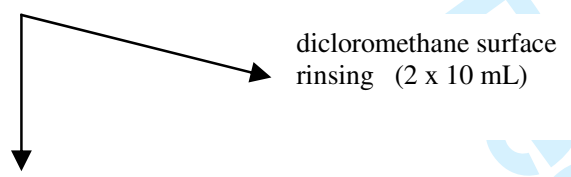

Fraction 3

Peeled and rinsed fruit

diatomaceous earth extraction

Fraction 4

Figure 2. Sample treatment scheme for penetration studies 


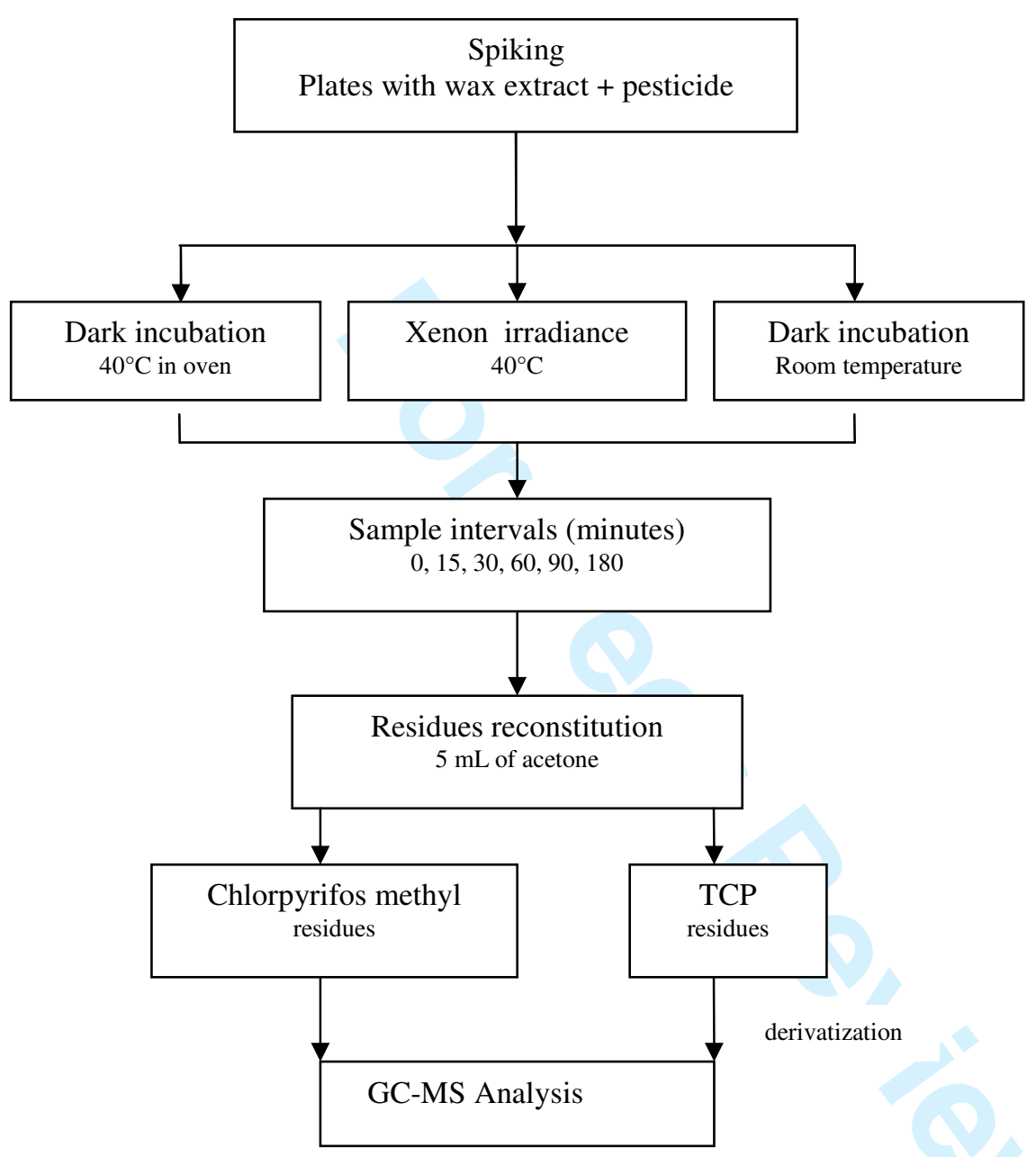

Figure 3. Spiking and sampling scheme for photodegradation experiments. 


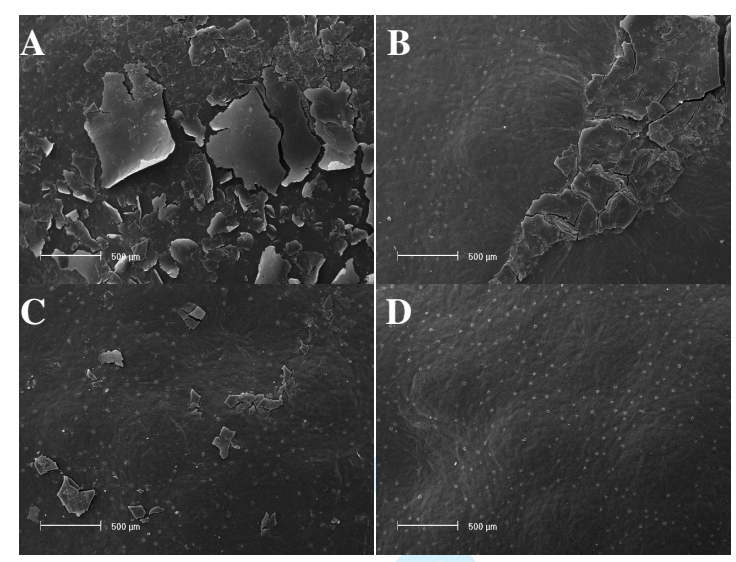

Figure 4. SEM observation of grapefruit surface, 5000x. a) without chloroform treatment; b) treated according to McDonald's procedure; c) warm chloroform; d) ultrasound. 
A



$\square$ WHOLE FRUIT $\square$ FRACTION 1 FRACTION 2 RRACTION 3 تFRACTION 4

B

Chlorpyrifo-methyl 0,008

residues $\left(\mu \mathbf{g} \mathbf{~ g}^{-1}\right) \quad 0,006$

0,004

GRAPERUTWAX+

GRAPERUTW WAX-

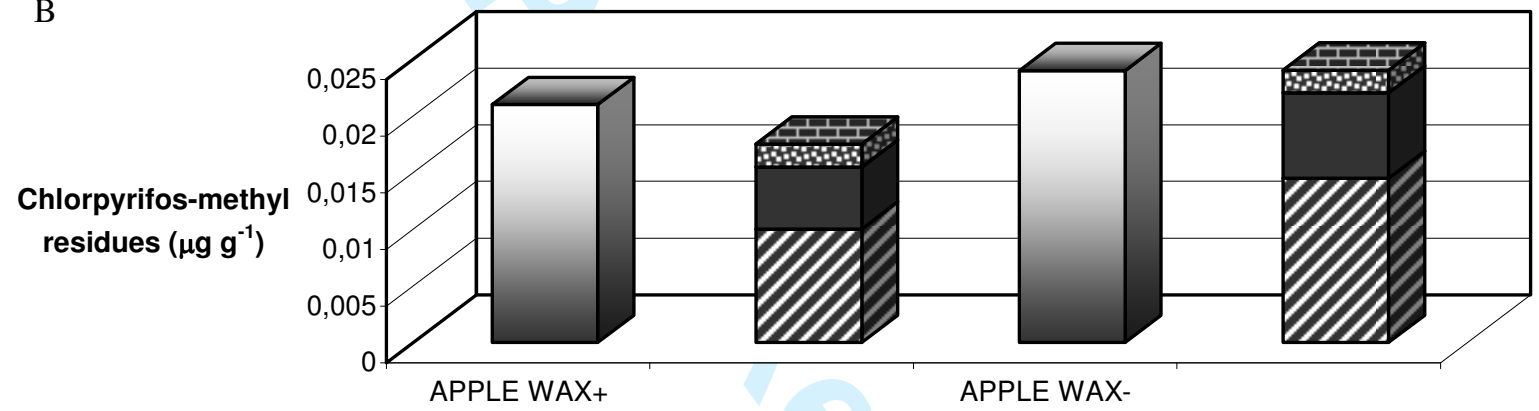

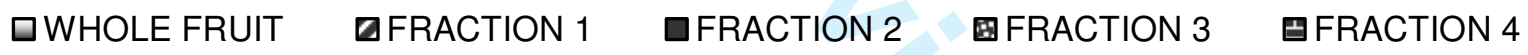

$\mathrm{C}$
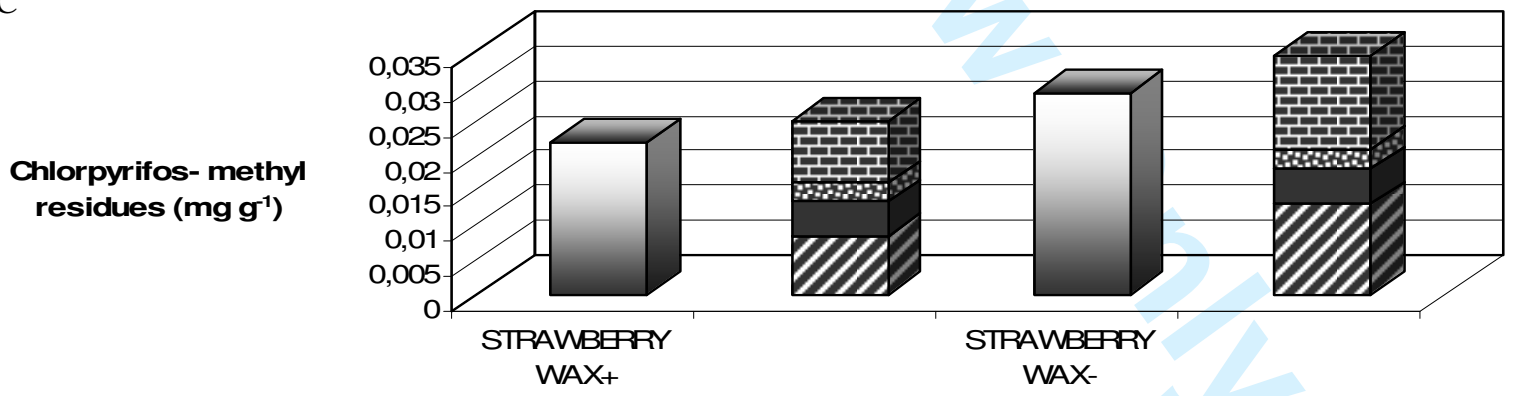

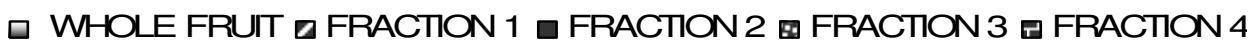


Figure 5. Total amount of chlorpyrifos methyl residues measured in the whole fruit and in four fractions of fruit, A grapefruit, B apple, C strawberry. 

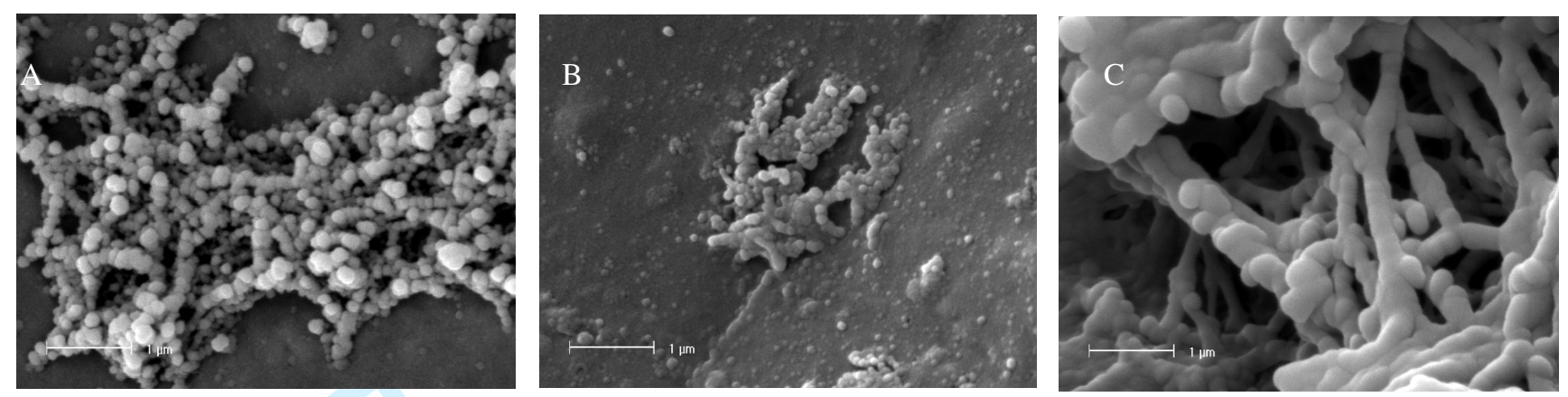

Figure 6. Scanning electron microscopy of waxes of strawberry (A), grapefruit (B), apple (C) (20000x magnification). 


\title{
Effect of surface waxes on the persistence of chlorpyrifos-methyl in apples, strawberries, and grapefruits.
}

\begin{abstract}
The effects of the cuticle and epicuticular waxes of grapefruit, strawberry and apple on the photodegradation and the penetration of chlorpyrifos-methyl were studied. Photodegradation experiments were conducted by exposing the insecticide to the light of a xenon lamp in the presence of a film of wax extracted from the fruit surface. The half-life of chlorpyrifos-methyl irradiated in absence of waxes was 9.6 min. The half-lives of pesticide irradiated in the presence of wax extracts of apple, grapefruit and strawberry were 83, 34, and 26 min respectively. In penetration studies, fruit with and without wax layers were treated with an aqueous suspension of pesticide. The penetration of the pesticide from the cuticle to the pulp was measured after 24 hours. Samples without wax contained a higher total amount of insecticide than those with wax. No pesticide was detected in samples of apple and grapefruit pulp. Residues were detected in all fractions of strawberry. The waxes and cuticle appear to have some effect on the photodegradation and penetration of chlorpyrifos-methyl in fruit samples.
\end{abstract}

Keywords: chlorpyrifos-methyl residue, fruit cuticle, photodegradation.

\section{Introduction}

Leaves and fruit are covered by a cuticle, an extracellular membrane consisting of a polymeric cutin matrix and soluble cuticular waxes. The portion of waxes embedded within the polymer framework is termed the intracuticular waxes, whilst the thin film on the surface of the cutin matrix comprises epicuticular waxes (Jetter and Schaffer, 2001). The latter forms the outermost boundary layer of the plant, representing an interface between the plant and the environment (Koch et al, 2004). The epicuticular waxes have important functional and physiological roles, such as the reduction of 
transpiration, maintenance of water balance, regulation of gas exchange, resistance to freezing and protection against pathogens, UV radiation and atmospheric pollutants (El-Otmani and Coggins, 1985).

These functionalities are due to specific chemical and physical properties. The epicuticalar waxes are a mixture of long chain compounds, such as hydrocarbons, ketones, alcohols, aldehydes, esters, and free and esterified fatty acid and related compounds (El-Otmani et al 1987). The composition and quantity of waxes vary between different vegetable species; within the same species there are also some variations in surface area and wax deposits, depending upon maturation, growth stage, environmental conditions etc. (Angioni et al, 2004 ). In the epicuticular wax of pineapple, navel oranges and dancy tangerine, paraffins accounted for $30-44 \%$ and $6-12 \%$ of the wax of immature and mature fruit, respectively (El-Otmani et al 1987), and during the fruit senescence a shift of nalkanes from higher to lower molecular weight components was observed (El-Otmani and Coggins, 1985). Physical description using microscope detection indicates a great micromorphological diversity of epicuticular waxes. Waxes may be developed as continuous layers, crusts or solitary crystalloids of varying thicknesses; the crystalloids are of differing shape and size and may appear in specific arrangements or combinations (Barthlot et al, 1998). The morphological study of epicuticular waxes was pioneered by de Bary in 1871. A more recent and refined classification, based on scanning electron microscopy (SEM) analyses of 13000 species, classified waxes into 23 types (Barthlot et al, 1998).

When a pesticide reaches fruit, either via agricultural application or deposition from the atmosphere, it can interact with the cuticle and the epicutical waxes through retention and/or absorption. Such processes tend to affect the fate of the pesticide and its efficacy as well as its persistence in the fruit (Kirkwood, 1999). The higher the pesticide persistence in the fruit, the higher the potential risk to the consumer via food intake. For this reason, studies of the effects of the cuticle and waxes on pesticide persistence can provide important data for the refinement of consumer risk assessment, and inform possible options for the mitigation of pesticide residues in 
food. Recent studies have indicated that the diffusion pathway of solutes, such as pesticides, within the transport limiting barrier of the cuticle has a large tortuosity which is reduced or removed upon the removal of waxes (Schönherr and Baur, 1994; and Baur et al, 1996).

The main aim of this paper was to evaluate the effects of the epicuticular waxes and cuticles of grapefruits, apples and strawberries on the penetration and dissipation of the pesticide chlorpyrifosmethyl. Chlorpyrifos-methyl (figure $1 \mathrm{~A}$ ) is an organophosphate (OP) insecticide, non-systemic, poorly soluble in water, with a low persistence and low mammalian toxicity (WHO/FAO, internet accessed 13 Nov 2005), in Europe it is widely used in the treatment of fruits, as diverse as soft, citrus, and pome fruits. The European Maximum Residues Limits (MRLs) for chlorpyrifosmethyl for strawberry, apple and grapefruit are set at $0.5,0.5$, and $0.05 \mu \mathrm{g} \mathrm{mg}^{-1}$ respectively (EUROPA- Plant Health- EU MRLs, internet accessed 26 Jan 2006).

[insert figure 1]

\section{Materials and methods}

\section{Fruit and chemicals}

Apples, strawberries and grapefruits cultivated on an organic farm were purchased from a supermarket.

Analytical standards of chlorpyrifos-methyl (99.4\% purity) and 3,5,6-trychloro-2 pyridinol (TCP) (99.5\% purity) were purchased from Labor Dr. Ehrenstorfer and Sigma respectively (figure 1 AB). Chloroform, ethanol, dichloromethane, hexane and acetone were HPLC grade solvents (CarloErba). Water was doubly distilled and purified with a MilliQ apparatus (Millipore, Milan) before use. Glutheraldehyde (purity 25\%) was obtained from Merck. Diatomaceous earth was obtained from Sigma-Aldrich. Stock standard solution of chlorpyrifos-methyl and TCP (1000 mg $\mathrm{L}^{-}$

$\left.{ }^{1}\right)$ were prepared in acetone. More dilute solutions were prepared by dilution of the stock solution 
with acetone. An aqueous suspension of chlorpyrifos-methyl, used to treat the fruit, was prepared by diluting the standard solution in distilled water, to obtain a concentration of $1 \mathrm{mg} \mathrm{L}^{-1}$.

\section{Procedure of extraction of fruit waxes}

Wax extraction was performed following the method of McDonald (1993). About $2500 \mathrm{~g}$ of fruits (apple, grapefruit and strawberry) were weighed then immersed in $2300 \mathrm{~mL}$ of chloroform for 2 min. The method was modified by: a) using warm chloroform $\left(45-50{ }^{\circ} \mathrm{C}\right)$, and b) using an ultrasonic apparatus $(190 \mathrm{~W}, 49 \mathrm{kHz})$. The fruit was then rinsed with clean chloroform. The final volume of chloroform extract was measured and a $10 \mathrm{~mL}$ portion of the extract was evaporated to dryness. Fruit at the same stage of ripening were measured with a calibre and their surface area was determined. The quantity of wax on the fruit surface $\left(\mu \mathrm{g} \mathrm{cm}^{-2}\right)$ was calculated from these data.

\section{Scanning electron microscopy (SEM) observation.}

Two rind samples $(1 \times 1 \mathrm{~cm})$ were excised with a scalpel from the equatorial zone of fruit with wax and fruit from which the wax had been removed. Samples were immediately fixed with $3 \%$ gluteraldehyde in phosphate buffer $(\mathrm{pH} 7.2)$ and cold-stored $\left(4^{\circ} \mathrm{C}\right)$ prior to further preparation. Fixed tissue was then rinsed three times in phosphate buffer $(\mathrm{pH}$ 7.2) followed by three washes in deionised water. Dehydration was performed using increasing concentrations of ethanol (20, 50, 70, 80, 95 and $3 \times 100 \%$ ethanol). Samples were retained for 20 min at each ethanol concentration step (Schirra et al, 1999). After completion in $100 \%$ ethanol, samples were critical point dried in a Baltec CPD 030 dryer and placed on aluminium stubs. Gold was sputter-coated in a Pabish Top Autocoater SC-20. SEM observations were carried out using a Philips XL30 ESEM microscope at $20 \mathrm{kV}$ and 5000x and 20000x magnification.

\section{UV Spectra}


An aliquot $(1 \mathrm{~mL})$ of the chloroform wax extract was dried under a stream of nitrogen and redissolved in $1 \mathrm{~mL}$ of hexane. Spectra of waxes were recorded using a UV-Visible Recording Spectrophotometer UV-160 (Shimadzu) ( $\lambda$ from 230nm to $800 \mathrm{~nm}$ ).

\section{Penetration studies}

The overall scheme of sample treatment applied in the penetration studies with fruit samples is shown in Figure 2. Fruit, with and without wax, were weighed (average weights of apple, grapefruit, and strawberry samples are $222.86 \pm 11.27 \mathrm{~g}, \quad 231.12 \pm 21.12 \mathrm{~g}$, and $8.34 \pm 0.66 \mathrm{~g}$ respectively) and immersed for 15 secs in an aqueous suspension of pesticide $\left(1 \mathrm{mg} \mathrm{L}^{-1}\right)$. To avoid losses, fruits were kept free of contact with surfaces, and left to dry at room temperature and in darkness. The treated fruit were divided into three aliquots. The first aliquot of fruit was weighed, milled, and extracted using diatomaceous earth in order to determine the amount of pesticide in the fortified samples $1 \mathrm{hr}$ after pesticide treatment. A second aliquot was weighed, milled, and extracted 24 hours after application. After $24 \mathrm{hr}$ from pesticide treatment, the third aliquot of fruit was used to obtain four fractions representing different depths, in order to perform the pesticide penetration study. The four fractions obtained were as follows:

1. Fruit was weighed and rinsed twice with $10 \mathrm{~mL}$ of dichloromethane. The rinses were collected and labelled fraction 1 .

2. Fruits was left to dry and then peeled by a very sharpened potato peeler to avoid squashing or destroying the fruits. The thickness of the peel was approximately $1 \mathrm{~mm}$. The peel was weighed, milled and extracted using the diatomaceous earth. The extract was labelled fraction 2 .

3. The remaining fruit was rinsed twice with $10 \mathrm{~mL}$ of dichloromethane. The rinses were collected and labelled fraction 3.

4. The sample was left to dry, milled and extracted with dichloromethane using diatomaceous earth; this extract was labelled fraction 4. 


\begin{abstract}
The experiment was carried out in triplicate. Untreated fruit was used as a control.
\end{abstract}
Concentration of fractions 1 and 3. Fractions 1 and 3 were concentrated by evaporating nearly to dryness at $30{ }^{\circ} \mathrm{C}$ using a vacuum rotary evaporator Heidolph (Selecta, Düsseldorf, Germany). The residue was dissolved in $10 \mathrm{~mL}$ of dichloromethane (to transfer it from a round bottle into a $10 \mathrm{~mL}$ vial), evaporated to dryness under a gentle stream of nitrogen at room temperature, dissolved in 1 $\mathrm{mL}$ of acetone and analysed using GC-MS.

Extraction of pesticide residues from fruit. Fruit samples (whole, peel and pulp) were milled and $5 \mathrm{~g}$ of the milled sample was mixed with $6.5 \mathrm{~g}$ of diatomaceous earth. Glass columns were filled with the mix and, after 10 minutes, were eluted with $100 \mathrm{~mL}$ of dichloromethane. The extract was concentrated and evaporated nearly to dryness at $30{ }^{\circ} \mathrm{C}$ using a vacuum rotary evaporator. The residue was dissolved in $10 \mathrm{~mL}$ of dichloromethane (to transfer it from a round bottle into a $10 \mathrm{~mL}$ vial), evaporated to dryness under a gentle stream of nitrogen at room temperature, dissolved in 1 $\mathrm{mL}$ of acetone and analysed using GC-MS. To calculate the recovery of extraction, $5 \mathrm{~g}$ of untreated milled apples (peel, pulp and whole fruit) were spiked with $1 \mathrm{~mL}$ of a $0.5 \mathrm{mg} \mathrm{L}^{-1}$ solution of pesticide, after which the samples were extracted as described and analysed using GC-MS.

[Insert figure 2 here]

\title{
Irradiation experiments
}

Light sources. A SunTest CPS/CPS+ Tabletop Xenon Exposure System with 1100 Watt air cooled xenon arc lamp, $\lambda$ from $280 \mathrm{~nm}$ to $800 \mathrm{~nm}$, (Atlas, Lochem The Netherlands) was used in the photo-degradation test.

An aliquot of the chloroform wax mixture (the volume of which was calculated so to give concentrations in the Petri dishes identical to concentrations found on the fruit surface) and $0.5 \mathrm{~mL}$ of a $5 \mathrm{mg} \mathrm{L}^{-1}$ solution of pesticide in acetone were poured into Petri dishes $(5 \mathrm{~cm}$ diameter, surface area approximately $20 \mathrm{~cm}^{2}$ ). The solvents were allowed to evaporate at room temperature, leaving a uniform film on the surface of the Petri dish. The dishes were placed into the Atlas SunTest, and 
were exposed for $180 \mathrm{~min}$ at $450 \mathrm{~W} \mathrm{~m}^{-1}$ and $40^{\circ} \mathrm{C}$. The residues on the plates were then dissolved in $5 \mathrm{~mL}$ of acetone and analysed directly to determine the chlorpyrifos-methyl residue. In order to determine TCP residue, $200 \mu \mathrm{L}$ of sample was derivatized by adding $20 \mu \mathrm{L}$ of $N, O$-bis(trimethylsilyl) trifluoroacetamide (BSTFA) and heating in an oven for $60 \mathrm{~min}$ at $60^{\circ} \mathrm{C}$ (Rudel et al., 2003). In all experiments, non-irradiated control samples were incubated in darkness at room temperature and in an oven at $40{ }^{\circ} \mathrm{C}$. Each experiment was performed in triplicate.

A schematic diagram of the spiking and sampling procedure is shown in figure 3.

Kinetics. The kinetics of loss of the pesticide were followed using GC-MS analysis. The rate constant of the disappearance of the pesticide was calculated as a pseudo first-order rate constant by $\mathrm{C}=\mathrm{C}_{0} \mathrm{e}^{-\mathrm{kt}}$

[Insert figure 3 here]

Apparatus and chromatography

GC-MS analysis was performed using an HP 6890 series gas chromatograph, equipped with an HP 5973 Mass Selective Detector and an HP 7683 series Injector (Hewlett-Packard). Chromatographic separation was performed on a ZB5 (Zebron) capillary column (30 m x $0.25 \mathrm{~mm}$ i.d.; $0.25 \mu \mathrm{m}$ film thickness). The carrier gas was helium, at a flow-rate of $1 \mathrm{~mL} \mathrm{~min}^{-1}$. The injector temperature was set at $250^{\circ} \mathrm{C}$, in splitless mode. The oven temperature was programmed as follows: $90{ }^{\circ} \mathrm{C}$ for $1 \mathrm{~min}$, increasing at $10^{\circ} \mathrm{C} \min ^{-1}$ to $140{ }^{\circ} \mathrm{C}$, increasing at $5{ }^{\circ} \mathrm{C} \min ^{-1}$ to $270{ }^{\circ} \mathrm{C}$ with a final hold for $10 \mathrm{~min}$ at $270{ }^{\circ} \mathrm{C}$. The injection volume was $1 \mu \mathrm{L}$. Electron impact of $1200 \mathrm{eV}$ was used for the ionisation of compounds. Analyses were carried out in select ion monitoring mode using the single ions: $\mathrm{m} / \mathrm{z}$ 286 and 254 for chlorpyrifos-methyl and derivatizated TCP, respectively.

\section{Results and discussion}




\section{Extraction of waxes}

The surface of grapefruit before and after chloroform treatment was examined by SEM to evaluate the extent of wax extraction. The peel of untreated fruit exhibited areas with wax layers in the form of rough, irregular platelets (figure 4-A). Wax platelets were still evident in the peel of chloroform treated grapefruit (figure 4-B). To improve wax extraction, more vigorous methods were applied: hot chloroform $\left(45-50^{\circ} \mathrm{C}\right.$ ) (figure 4-C), and using the ultrasonic apparatus (figure 4-D).Complete extraction of waxes from the grapefruit surface was achieved using ultrasound. The surface of grapefruit free of wax is shown in figure 4-D. Wax extraction was performed using this procedure for all fruit types considered in the study, including strawberries, for which the method was found to be effective but not harmful to the delicate surface of the fruit.

The amount of wax extracted from strawberry, grapefruit and apple was 22,130 and $516 \mu \mathrm{g} / \mathrm{cm}^{2}$ respectively (table 1). The amount of wax extracted from the apple was lower than that obtained in previous work (Angioni et al, 2004). This difference could be attributed to differences in the variety, maturation and growth stage of the fruit used in the study, and the environmental conditions to which it had been subjected.

[Insert figure 4 here]

[Insert table 1 here]

\section{Dose-response curves and limits of quantification of chlorpyrifos-methyl and TCP}

Quantification of chlorpyrifos-methyl and derivatizated TCP was performed by external standard procedure. 10 concentrations of pesticide and derivatizated metabolite (ranged from $0.001 \mu \mathrm{g} \mathrm{mL}^{-1}$ to $10 \mu \mathrm{g} \mathrm{mL} L^{-1}$, and from $0.006 \mu \mathrm{gL}^{-1}$ to $10 \mu \mathrm{g} \mathrm{mL}^{-1}$, respectively) were injected 3 times to $\mathrm{GC}$ MS. Chlorpyrifos-methyl showed a linear response with a correlation coefficient of 0.99 ; the repeatability value, expressed as the relative standard deviation (R.D.S.) of ten determinations, was $2.8 \%$; the limit of quantification (LOQ) was $0.001 \mu \mathrm{g} \mathrm{g}^{-1}$. Derivatizated TCP showed a linear coefficient of 0.99; the repeatability value, expressed as the R.D.S. of 10 determinations, was 5\%; the LOQ was $0.005 \mu \mathrm{g} \mathrm{g}^{-1}$. 


\section{Recovery of the pesticide extraction method}

Apples fortified with $0.1 \mu \mathrm{g} \mathrm{g}^{-1}$ of pesticide were extracted with diatomaceous earth. Recoveries were satisfactory for all samples of whole apple, apple peel, and apple pulp (95, 91, and 98\% respectively). The R.D.S. for 3 replicates always was less than $9 \%$.

\section{Penetration studies}

No pesticide decay was observed in fruit samples analysed 1 hour and 24 hours after pesticide treatment (tables 2,3,4).

The concentration of pesticide residues in whole fruit 24 hours after treatment were $0.022,0.021$ and $0.012 \mu \mathrm{g} \mathrm{g}^{-1}$ for strawberry, apple and grapefruit respectively (tables 2,3,4). This indicates variation in the penetration capacities of the same OP pesticide between several fruit species with different wax structures.

Residues of chlorpyrifos-methyl were below the LOQ in the third and fourth fractions of grapefruit, both with and without wax. This indicates that penetration into the grapefruit is low, probably due to the impermeable structure of its peel. The amount of residues in the peel samples from which the wax had been removed were higher than those with the wax intact $\left(0.047\right.$ and $0.013 \mu \mathrm{g} \mathrm{g}^{-1}$, respectively). These data indicate the low permeability of the waxes to chlorpyrifos-methyl (table 2).

24 hours after treatment, chlorpyrifos-methyl residues were detected in the first, second and third fractions of apple, but not in the apple pulp (table 3). In studies of the penetration of other OPs, residues of fenitrothion, malathion and ethiofencarb were detected in the internal fractions of apple one day after the treatment, whilst diclofluanid did not penetrate into the fruit (Perez Clavijo et al, 1996). As for the grapefruit samples, the amount of chlorpyrifos-methyl determined in samples of apple from which the wax had been removed was significantly higher than from samples with wax intact $\left(0.129\right.$ and $0.095 \mu \mathrm{g} \mathrm{g}^{-1}$ respectively). 
As shown in table 4, pesticide residues were detected in all fractions of strawberry, which indicates that penetration into the fruit is high, due to the permeable structure of the skin. In particular, the high penetration and accumulation of pesticide into the pulp of chloroform treated strawberries was observed.

[Insert table 2, 3, and 4 here]

The total amount of residue [measured residue $\left(\mu \mathrm{g} \mathrm{g}^{-1}\right) \times$ media weight of fruit $(\mathrm{g})$ ] detected in the whole fruit and in the four fractions is shown in figure 5.

The total amount of pesticide residues was greater in fruit samples from which the wax was removed compared to those in which the wax was intact (figure $5 \mathrm{~A}, \mathrm{~B}, \mathrm{C}$ ). These results confirm the protective role of waxes against the penetration of pesticides (El-Otmani and Coggins, 1985; Kunst and Samuel, 2003) and other aerial contaminants (Gòrna-Binkul et al, 2001) present in the atmosphere which can be taken up by plants, accumulate, and ultimately enter the human food chain, thus becoming important in terms of risk to human health.

The amount of pesticide residue detected in the waxes and in the peel was approximately $100 \%$ and $91 \%$ of the total amount detected in grapefruit and apple samples respectively, both in samples with and without wax (figure $5 \mathrm{~A}$ and $\mathrm{B}$, respectively). In strawberry samples, the total amount of residue was distributed equally between the external and internal fractions (figure $5 \mathrm{C}$ ). [Insert figure 5 here]

\section{Photodegradation studies}

Chlorpyrifos-methyl is a broad-spectrum organophosphate insecticide of relatively low toxicity and persistence. The major products of transformation are TCP and $O, O$-dimethyl phosphate. The photoproducts of evaporated chlorpyrifos-methyl in humid are TCP, hydroxylated pyridinol derivatives, and oxidation products of quinine structures (WHO Pesticide Residues Series, internet accessed 13 November 2005). 
During the photodegradation tests reported herein, chlorpyrifos-methyl was exposed to light in the presence of a film of wax equal to that found the surfaces of the fruit species considered. The degradation rate of chlorpyrifos-methyl was calculated using pseudo first order kinetics. Table 5 shows half-lives $\left(t_{1 / 2}\right)$ and correlation coefficients $(r)$ of chlorpyrifos-methyl. The half-life of pesticide irradiated in the absence of waxes was $9.6 \mathrm{~min}$. The decay rate of chlorpyrifos methyl was slightly reduced by strawberry wax $\left(\mathrm{t}_{1 / 2}=26 \mathrm{~min}\right.$.), and was further reduced in the presence of grapefruit wax $\left(\mathrm{t}_{1 / 2}=34 \mathrm{~min}.\right)$ and apple wax $\left(\mathrm{t}_{1 / 2}=83 \mathrm{~min}.\right)$.

During irradiation inside the Suntest apparatus, the temperature was approximately $40{ }^{\circ} \mathrm{C}$. To investigate if this temperature influenced the persistence of the pesticide, non-irradiated control samples were held in darkness at room temperature (approximately $25{ }^{\circ} \mathrm{C}$ ) and at $40{ }^{\circ} \mathrm{C}$. No temperature effect was observed. The $t_{1 / 2}$ of chlorpyrifos-methyl measured on plates held in darkness at room temperature and at $40^{\circ} \mathrm{C}$ in the presence of strawberry waxes was 277 and 250 min, respectively. In the presence of grapefruit and apple waxes, values of $t_{1 / 2}$ were 385 and 577 , 577 and 650 min respectively.

The presence of wax on the fruit surface affects the photodegradation of chlorpyrifos-methyl. The rate of photodegradation decreases in the presence of fruit wax. We can hypothesize that the radiation is adsorbed by wax, and only the $\lambda$ that penetrate the waxes can interact with the pesticide molecule. This decrease in radiation intensity results in a decrease in the rate of photodegradation (Pirisi et al, 1998).

The major metabolite resulting from irradiation of chlorpyrifos-methyl is TCP (Figure 1B). This metabolite is also a degradation product of chlorpyrifos and triclopyr (Morgan et al 2004). For this reason, control plates were assessed for the absence of TCP. During the photo-degradation experiments TCP formation was monitored. Some TCP formation was observed, and TCP formed via photolytic degradation was less photolytically stable than chlorpyrifos-methyl itself (table 5). However, the formation of TCP may not be exclusively due to photolysis . It is possible that the primary mechanism of production of TCP, in some cases, was unrelated to the presence of sunlight. 
TCP is photolytically unstable and it may not be detected during aqueous photolysis studies. A $100 \%$ photo-degradation within 24 hours of an aqueous buffer ( $\mathrm{pH} 8$ ) containing 100,000 mg kg-1 of TCP has been reported. Furthermore, following photolytic exposure of a $1 \mathrm{mg} \mathrm{kg} \mathrm{gaeus}^{-1}$ solution of TCP, an estimated half-life of 4.4 min was reported for a water body surface at a latitude of $40^{\circ}$ north (Ware, 1993).

[Insert table 5 here]

The data reported herein confirm results obtained by Angioni et al. (2004) who found an increase in the half-life of rotenone in the presence of waxes for irradiated eggplant, although they did not observe interference of waxes with photodegradation. Cabras et al, (1997) demonstrated that wax composition, rather than film thickness, was responsible for the increase in half-life of fenthion.

The penetration rate and the dissipation of chlorpyrifos-methyl varied between the fruit species considered. This can be attributed to the chemical and physical characteristics of the waxes. SEM observations of the waxes of strawberry, grapefruit and apple suggest that the crystalloid forms of wax have different structures and shapes (figure 6). Strawberry and grapefruit waxes are organized in a granular structure, whilst the apple waxes had a more tubular structure. The UV spectra of wax extracts in the range of $230-800 \mathrm{~nm}$ show a rather similar absorbance for grapefruit and apple with a maximum absorbance at $230 \mathrm{~nm}$, whilst the strawberry spectra show a different profile (data not shown).

[Insert figure 6 here]

\section{Conclusion}

Although chlorpyrifos-methyl residues do not present a risk to the consumer (as demonstrated in the most recent European risk assessments (Commission Directive 2005/72/EC, 2005), some samples of fruit, vegetables and cereals analysed in monitoring studies performed in Italy and Europe indicate the presence of chlorpyrifos-methyl residues (Italian Pesticide Residues Monitoring Report 2001, 2002, 2003, 2004; Annual EU-Wide Pesticide Residues Monitoring Report 2003, 2002, 2001, 
1999, 1998, 1996; internet accessed 26 Jan 2006). In order to minimise residue levels during food processing, the rate of losses of pesticides should be assessed for the main fruit and vegetable compartments. The results reported in this paper confirm that the epicuticular waxes and cuticle influence pesticide persistence, mainly through protecting the pesticide and its transformation products from photolysis. Most of the pesticide is absorbed and only a small portion passes through the barrier of the cuticle and penetrates into the pulp. However, the extent of these processes are species dependent as the chemical and physical properties of the cuticle vary between species. In the case of this study, strawberry showed no "surface effect" compared to apple and grapefruit.

These studies can provide important information regarding options for the reduction of pesticide residues in food. Through the use of adapted food processing methods, for example, peeling, washing or brushing, residues of chlorpyrifos-methyl and its metabolites in food can be decreased, so meeting specific legislative requirements (e.g. baby food) and specific market requirements, as well as consumer needs.

\section{References}

Angioni, A., Cabizza, M., Cabras, M., Melis, M., Tuberoso, C., Cabras, P. 2004. Effect of the epicuticular waxes of fruits and vegetables on the photodegradation of rotenone. Journal of Agricultural and Food Chemistry. 52:3451-3455

Barthlot, W., Nienhuis, C., Cutler, D., Ditsch, F., Mesusel, I., Theisen, I., Whilhelmi, H. 1998. Classification and terminology of plant epicuticular waxes. Botanical Journal of the Linneam Society. 126: 237-260.

Baur, P., Marzouk, H. and Schönherr, L. 1996. Mobilities of organic compounds in plant cuticles as affected by structure and molare volumes of chemical and plant species. Planta. 199: 404-412. 
Cabras, P., Angioni, A., Garau V.L., Melis, M., Pirisi, F.M., MinelliE.V. 1997. Effect of the epicuticular waxes of fruits on the photodegradation of fenthion. Journal of Agricultural and Food Chemistry. 45:3681-3683.

Commission Directive 2005/72/EC of 21 October 2005 amending Council Directive 91/414/EEC to include chlorpyrifos, chlorpyrifos-methyl, mancozeb, maneb, and metiram as active substances. 2005. Official Journal L. 279:63-69.

de Bary A. 1871.Ueber die Whachsüberzüge de Epidermis. Botanische Zeitschrift. 29: 128-154.

El-Otmani, M., Arpaia, M.L., Coggins, C.W. 1987.Development and topophysical effects on the nalkanes of Valencia orange fruit epicuticular wax. Journal of Agricultural and Food Chemistry. 35: $42-46$.

El-Otmani, M.,; Coggins, C.W. 1985. Fruit development and growth regulator effects on normal alkanes of Washinton navel orange fruit epicuticular wax. Journal of Agricultural and Food Chemistry, 33:656-663.

EUROPA- Plant Health- EU MRLs sorted by pesticide [internet]. Available from: http://europa.eu.int/comm/food/plant/protection/pesticides/index_en.htm accessed 200626 January.

Food and Veterinary Office - Special Reports: Annual EU-wide Pesticide Residues Monitoring Report 2003. Available from:

http://europa.eu.int/comm/food/fvo/specialreports/pesticides_index_en.htm. Accessed 200626 January.

Food and Veterinary Office - Special Reports: Annual EU-wide Pesticide Residues Monitoring Report 2002. Available from:

http://europa.eu.int/comm/food/fvo/specialreports/pesticides_index_en.htm. Accessed 200626 January.

Food and Veterinary Office - Special Reports: Annual EU-wide Pesticide Residues Monitoring Report 2001. Available from: 
http://europa.eu.int/comm/food/fvo/specialreports/pesticides_index_en.htm. Accessed 200626 January.

Food and Veterinary Office - Special Reports: Annual EU-wide Pesticide Residues Monitoring Report 1999. Available from:

http://europa.eu.int/comm/food/fvo/specialreports/pesticides_index_en.htm. Accessed 200626 January.

Food and Veterinary Office - Special Reports: Annual EU-wide Pesticide Residues Monitoring Report 1998. Available from:

http://europa.eu.int/comm/food/fvo/specialreports/pesticides_index_en.htm. Accessed 200626 January.

Food and Veterinary Office - Special Reports: Annual EU-wide Pesticide Residues Monitoring Report 1996. Available from:

http://europa.eu.int/comm/food/fvo/specialreports/pesticides_index_en.htm. Accessed 200626 January.

Gòrna-Binkul, A., Kraczmarski, K., Buszewski, B. 2001. Modeling of the sorption and diffusion process of volatile organic air pollutants in grape fruits. Journal of Agricultural and Food Chemistry. 49: 2889-2893.

Jans, U. and Hasan Miah, M. 2003. Reaction of chlorpyrifos-methyl in aqueous hydrogen sulphide/bisulfide solutions. Journal of Agricultural and Food Chemistry. 51: 1956-1960.

Jetter, R.; Schaffer, S. 2001.Chemical composition of the Prunus laurocerasus leaf surface. Dynamic changes of the epicuticular wax film during leaf development. Plant Physiology 126(4):1725-1737.

Kirkwood, R.C. 1999. Recent developments in our understanding of the plant cuticle as a barrier to the foliar uptake of pesticide. Pesticide Science. 55: 69-77.

Koch, K,. Neinhuis, C., Ensikat, H.J., Barthlott, W. 2004. Self assembly of epicuticular waxes on living plant surfaces imaged by atomic force microscopy (AFM). Journal of Experimental 
Botany 55(397):711-8. Epub 2004 Feb 13.

Kunst, L., Samuel, A. L. 2003. Biosynthesis and secretion of plants cuticular waxes. Progress in lipid research. 42: 51-80.

Martin, J.T.; Juniper, B.E. Methods of research on Cuticles. In The cuticles of plants, edition I; Arnold, E., Eds.; Publisher: Edinburgh, Great Britan, 1970; 16-53.

Mc Donald, R.E., Nordby, H.E, McCollum, T.G. 1993. Epicuticular Wax morphology and composition are related to grapefruit chilling Injury. HortScience. 28:311-313.

Ministero della Salute Italiano, Controllo ufficiale sui residui di prodotti fitosanitari negli alimenti di origine vegetale - Risultati in Italia per l'anno 2003 - Luglio 2004. Available from: http://www.ministerosalute.it/alimenti/sicurezza/sicApprofondimento.jsp?lang=italiano\&label=con \&id=296 accessed 200626 January.

Ministero della Salute Italiano, Controllo ufficiale sui residui di prodotti fitosanitari negli alimenti di origine vegetale - Risultati in Italia per l'anno 2004 - Luglio 2005. Available from: http://www.ministerosalute.it/alimenti/sicurezza/sicApprofondimento.jsp?lang=italiano\&label=con \&id=296 accessed 200626 January.

Ministero della Salute Italiano, Controllo ufficiale sui residui di prodotti fitosanitari negli alimenti di origine vegetale - Risultati in Italia per l'anno 2002 - Giugno 2003. Available from: http://www.ministerosalute.it/alimenti/sicurezza/sicApprofondimento.jsp?lang=italiano\&label=con \&id=296 accessed 200626 January.

Ministero della Salute Italiano, Controllo ufficiale sui residui di prodotti fitosanitari negli alimenti di origine vegetale - Risultati in Italia per l'anno 2001 - Giugno 2002. Available from: http://www.ministerosalute.it/alimenti/sicurezza/sicApprofondimento.jsp?lang=italiano\&label=con \&id=296 accessed 200626 January.

Morgan, M. K., Sheldon, L. S., Croghan, C.W., Jones, P.A., Robertson, G.L.; Chuang, J.C.; Wilson, N.K.; Lyu, C.W. 2004. Exposures of preschool children to chlorpyrifos and its degradation product 
3,5,6-trichloro-2-pyridinol in their everyday environments. Journal of Exposure Analysis and Environmental Epidemiology.15: 1-13

Perez Clavijo, M., Plaza Medina, P., Sanz Asensio, J., Galbán Bernal, J. 1996. Decay study of pesticide residues in apple samples. Journal Chromatography A. 740: 146-150.

Pirisi, F.M., Angioni, A., Cabizza, M., Cabras, P., Maccioni, E. 1998. Influence of Epicuticular Waxes on the Photolysis of Pirimicarb in the Solid Phase. Journal of Agricultural and Food Chemistry. 46:762-765.

Rudel, R.A., Camann, D.E., Spengler, J.D., Korn, L.R., Brody, J.G. 2003. Phthalates, alkylphenols, pesticides, polybrominated diphenyl ethers, and other endocrine-disrupting compounds in indoor air and dust. Environmental Science \& Technology. 37:4543-53.

Saenz Barrio, C., Sanz Asensio, J., Plaza Medina, P., Perez Clavijo, M. 1995.Evaluation of the decay of malathion, dichlofluanid and fenitrothion pesticides in apple sample, using gas chromatography. Food Chemistry. 52:305-309

Schirra, M., D’hallewin, G., Inglese, P.; La Mantia, T. 1999. Epicuticular changes and storage potential of cactus pear [Opuntia ficus-indica Miller (L.)] fruit following gibberellic acid preharvest sprays and postharvest heat treatments. Postharvest Biology and Technology. 17: 79-88

Schönherr, L. and Baur, P. 1994. Modelling penetration of plant cuticles by crop protection agents and effects of adjuvants on their rates of penetration. Pesticide Science. 42: 185-208.

Ware, G.W. 1993. Reviews of environmental contamination and toxicology, Publisher SpringerVerlag, USA. 131: 60-64.

WHO Pesticide Residues Series 5; Chlorpyrifos-methyl [internet]. Available from: www.inchem.org/documents/jmpr/jmpmono/v075pr12.htm. accessed 200513 November.

WHO/FAO Chlorpyrifos-methyl (PDS) [internet]. Available from: www.inchem.org/documents/pds/pds/pest33_e.htm. Accessed 200513 November. 